\title{
Zapomniany panegiryk Ignacego Srzednickiego ku czci Kazimierza Nestora Sapiehy
}

Niebudząca dotychczas zainteresowania ulotka Ignacego Śrzednickiego zatytułowana Jaśnie Oświeconemu Księciu Jmci Saphyi, generałowi szefowi artyl[erii] W[ielkiego] Ks[ięstwa] Lit_[ewskiego], marszałkowi Skonf[ederowanych] Stanów Najjaś[niejszej] Rze[czy]p[ospo]l[i]tej Polskiej z Wielkiego Księstwa Litewskiego. Wielkiemu niespracowanemu dzielnej duszy mężowi wieśniak spod cienia wiejskiego stanu na wielki i wysoki świat przybywszy dzieło moje partykularne w ręce Pańskie ofiaruję intryguje zarówno ze względu na autora, jak i adresata. Egzemplarze tego druku znajdują się w zbiorach Biblioteki Instytutu Badań Literackich w Warszawie, Biblioteki Wojewódzkiej w Kielcach i Biblioteki im. Ossolińskich we Wrocławiu ${ }^{1}$. Wydano je anonimowo typograficznie, ale dzięki ustaleniu Józefa Szczepańca wiemy, że wyszły spod prasy Drukarni Wolnej Jana Potockiego w Warszawie w 1791 roku $^{2}$. Wobec braku anonsu prasowego, który pozwoliłby doprecyzować czas edycji, przyjmujemy, że utwór ogłoszono przed uchwaleniem Konstytucji 3 maja, o której nie ma żadnej wzmianki w wierszu. Podana w tytule utworu ranga generała artylerii litewskiej oraz pełniona funkcja marszałka litewskiego sejmu i konfederacji generalnej Obojga Narodów przez Kazimierza Nestora Sapiehę wskazują, że mamy do czynienia z tekstem z czasu Sejmu Wielkiego, co potwierdza ustalenie wrocławskiego badacza.

Poza informacją dotyczącą adresata wiersza druk ulotny zawiera dane odnoszące się do autora tekstu: „Ignacy na Srzednicy”, „obywatel województwa podla-

${ }^{*}$ Prof. dr hab., Uniwersytet Gdański, Wydział Filologiczny, Instytut Filologii Polskiej, Katedra Historii Literatury, ul. Wita Stwosza 55, 80-308 Gdańsk. Aktualnie: PWSZ w Elblągu, Instytut Pedagogiczno-Językowy, Filologia Polska, 82-300 Elbląg, ul. Czerniakowska 22; e-mail: krmaks@interia.pl

${ }^{1}$ B.m.r., k. nlb. 2: Biblioteka IBL w Warszawie, sygn. XVIII 2.193, stąd wydanie cyfrowe; Biblioteka Wojewódzka w Kielcach, sygn. Qu 895 adl.; Biblioteka im. Ossolińskich we Wrocławiu, sygn. XVIII 8575. Wymienione egzemplarze druku znane są autorce tego studium. K. Estreicher, Bibliografia polska, cz. 3, t. 29 (40), wyd. S. Estreicher, nakł. Polskiej Akademii Umiejętności, Kraków 1933, s. 147.

${ }^{2}$ J. Szczepaniec, Drukarnia Wolna Jana Potockiego w Warszawie 1788-1792, Wydawnictwo Uniwersytetu Wrocławskiego, Wrocław 1998, s. 263. 
skiego ziemi bielskiej”, „wieśniak spod cienia wiejskiego stanu na wielki i wysoki świat przybyły”, „Srzednicki”. Wobec braku biogramu Ignacego Srzednickiego w Polskim Stowniku Biograficznym oraz nieobecności w Nowym Korbucie, jak też pomijania w źródłach z epoki i w opracowaniach, ustalenia biograficzne dotyczące tego autora są wyzwaniem dla badaczy. Na polu poszukiwań wiadomości o Ignacym Srzednickim istotne usługi oddaje Katalog szlachty, opracowany przez Leszka Koconia, oparty w głównej mierze na aktach metrykalnych. Zawarte w nim dane odnoszą się zarówno do autora będącego w centrum zainteresowania tego wiersza, jak też do jego rodziny.

Twórca panegiryku adresowanego do Kazimierza Nestora Sapiehy urodził się w 1772 roku. Mieszkał w Kobylinie Pieniążkach i tam przychodziły na świat jego dzieci: Barbara (ur. 1801), Zuzanna (ur. 1807), Dominik (ur. 1810) i Weronika (ur. 1815). W tej samej miejscowości urodził się młodszy o jeden rok od Ignacego jego brat Józef (ur. 1773), co pozwala sądzić, że w Kobylinie Pieniążkach także Ignacy rozpoczął swój żywot. Pewność mamy co do miejsca śmierci Ignacego Srzednickiego. Według Katalogu szlachty zmarł w Kobylinie Pieniążkach 1 sierpnia 1831 roku, przeżywszy 59 lat. Pozostałe informacje zawarte w Katalogu odnoszą się do rodziców oraz małżonki Ignacego Srzednickiego: był synem Andrzeja i Zuzanny z Piszczatowskich, a mężem Marianny (Barbary) z Bobińskich ${ }^{3}$.

Zamieszczone w Słowniku geograficznym Królestwa Polskiego i innych krajów stowiańskich hasło Kobylino informuje o ośmiu wioskach (osadach) objętych tą jedną wspólną nazwą. Kobylino Pieniążki zawdzięcza swą nazwę Mikołajowi Pieniążkowi, który na początku XVI wieku wszedł w posiadanie jednej z osad należących do Kobylina. W 1775 roku (autor wiersza miał wówczas trzy lata) Kobylino liczyło „domostw sto dwadzieścia dwa, z tych dziesięć proboszczowskich, a sto dwanaście szlacheckich. Jeden szlachcic miał domostw dziesięć, jeden sześć, jeden trzy, pięciu po dwa, a ośmdziesięciu trzech po domostwie jednym"4. $\mathrm{Z}$ tego wynika, że w 1775 roku Srzedniccy byli jedną z osiemdziesięciu trzech rodzin szlacheckich Kobylina i plasowali się w przedziale od jednego do dziesięciu domostw. Statystyka ta niewiele zmieniła się pod koniec życia Ignacego Srzednickiego. Według tego samego Słownika w 1827 roku miejscowość liczyła sto trzydzieści pięć domostw, co oznacza, że przez pół wieku przybyło ich trzynaście. Czy nasz poeta miał jakiś wpływ na to wyliczenie? Na tak postawione pytanie należałoby chyba odpowiedzieć twierdząco, ponieważ dzieci Srzednickiego usamodzielniały się, zawierały związki małżeńskie w Kobylinie i tam dokonywały żywota.

Z perspektywy niniejszego studium najistotniejsza jest twórczość literacka Srzednickiego. Tu z pomocą przychodzi Bibliografia polska Estreichera, w któ-

${ }^{3}$ www.katalogszlachty.com, s. 24-25; dostęp: 10.02.2016 r. Autor strony internetowej: Leszek Kocoń.

${ }^{4}$ Słownik geograficzny Królestwa Polskiego i innych krajów słowiańskich, nakł. F. Sulimierskiego i W. Walewskiego, t. 4, Warszawa 1883, s. 216-217. 
rej odnotowano dwa utwory poetyckie autora. Jeden z nich (wyżej wymieniony w tym studium) adresowany jest do Kazimierza Nestora Sapiehy; drugi nosi tytuł Jaśnie Wiel[możnemu] na Małachowicach Nałęcz Małachowskiemu, referend[arzowi] koron[nemu], marszałkowi Najjaś[niejszej] Rze[czy]p[ospo]l[i]tej Polskiej Skonf[ederowanych] Stanów Koronnych, Kawalerowi Orderów Orła Białego i Sw. Stanisława. Sandeckiemu, Knyszyńskiemu etc. Staroście. Wielkiemu niespracowanemu dzielnej duszy mężowi wieśniak spod cienia wiejskiego stanu na wielki $i$ wysoki świat przybywszy dzieło moje partykularne w ręce Pańskie ofiaruję 5 .

Utwór adresowany do marszałka Stanisława Małachowskiego wydano (tak jak wiersz poświęcony Sapieże) anonimowo typograficznie, tą samą czcionką i z częściowo (drugi człon tytułu i addytament) identycznie brzmiącym tekstem. To świadczy, że panegiryk ku czci Małachowskiego - podobnie jak adresowany do Sapiehy - wyszedł spod prasy Drukarni Wolnej Jana Potockiego. Publikacja obu utworów w Warszawie i w zbliżonym, a możliwe, że nawet w tym samym czasie, zdaje się sugerować, że autor mógł przebywać wówczas w stolicy. W roku ogłoszenia wierszy był młodym człowiekiem - miał lat osiemnaście. Okoliczności publikacji mogły się zatem łączyć z jego edukacją, chociaż równie dobrze mógł przybyć do Warszawy kierowany entuzjazmem dla działalności Sejmu Wielkiego, by w miejscu obrad śledzić poczynania sejmujących i oddychać atmosferą rozpolitykowanej stolicy. Taką szansę mogłoby mu zapewnić pijarskie Collegium Nobilium, ukierunkowane na kształcenie postaw obywatelskich. Ucząca się tam młodzież była zapraszana do parlamentu i - co więcej - ułatwiano jej kontakty z ówczesnymi osobistościami. W dobie Sejmu Czteroletniego Srzednicki (jak wielu) docenił wagę doniosłości obrad, czemu dał wyraz w wierszach adresowanych do marszałków sejmowych. Jeśli dodamy do tego umiejętność posługiwania się przez niego łaciną (okolicznościowe motta łacińskie do wierszy) i składania rymów, to domysły na temat jego edukacji nie są bezpodstawne, chociaż w tej kwestii zdani jesteśmy tylko na spekulacje. Nie mamy też większej wiedzy na temat aktywności Srzednickiego na niwie literackiej. Poza dwoma wyżej wymienionymi wierszami jego autorstwa inne dokonania pisarskie tego twórcy nie zostały odnotowane. Można przyjąć, że ogłoszone drukiem wiersze stanowiły jednorazowy „fajerwerk” Srzednickiego na polu literackim, co nie wyklucza jego parania się rymowaniem w kręgu rodzinnym czy przyjacielskim. Na obecnym etapie badań nie znamy jednak utworów Srzednickiego z nieoficjalnego obiegu.

Niejasna jest kwestia ewentualnych powiązań autora z Kazimierzem Nestorem Sapiehą, któremu pozycją społeczną nie dorównywał. Mienił się jego „najlichszym sługą", co było wyrazem szczególnego szacunku dla adresata, aczkolwiek był to zwrot konwencjonalny w ówczesnej korespondencji. Ponieważ posiadłość Koby-

${ }^{5}$ B.m.r., k.nlb. 2: Biblioteka IBL w Warszawie, sygn.: XVIII 2.192, stąd wydanie cyfrowe. K. Estreicher, dz. cyt., s. 147. 
lino Pieniążki znajdowała się w tym samym województwie podlaskim co Kodeń Sapiehów, można podejrzewać, że odczuwał więź terytorialną z bohaterem swego panegiryku i mógł uważać się za sąsiada szacownego domu książęcego Sapiehów. A że dom ten zapewne budził jego ciekawość, zdaje się świadczyć wprowadzona do wiersza oboczna forma nazwiska adresata „Saphia”. Było to nawiązanie do Semena, założyciela rodu o przydomku „Sopiha”, który w pierwszej połowie XV stulecia występował w roli pisarza hospodarskiego, a jego syna Iwana (Iwaszko), mającego zasługi w dyplomacji, uważa się za protoplastę linii kodeńskiej Sapiehów ${ }^{6}$. Odwołanie do antenata rodu przywoływało na myśl kilkuwiekową tradycję domu sapieżyńskiego, a ta - jak wiadomo - budowała prestiż magnaterii. Poeta, mieszkaniec Podlasia, mógł nadto chcieć zaznaczyć powinowactwo terytorialne $\mathrm{z}$ adresatem wiersza. Ponieważ wśród Sapiehów nie brakowało wybitnych postaci, pracujących na rzecz podnoszenia statusu rodu, można by oczekiwać, że antenaci zostaną przywołani w utworze zgodnie z wypracowanym w literaturze schematem genealogii rodów. W pewnym stopniu zasadzie tej hołduje Srzednicki w wierszu do Stanisława Małachowskiego, w którym przywołuje imiona znakomitych członków tego rodu. Były to jednak postaci z najbliższego planu czasowego adresata, czyli bracia i ojciec. Ojcu, kanclerzowi wielkiemu koronnemu, Janowi Małachowskiemu, poświęcił spory fragment wiersza, co w kontekście bezsprzecznych zasług magnata $\mathrm{w}$ zakresie budowania potęgi rodu oraz jego prestiżu na dworze królewskim i popularności wśród szlachty było jak najbardziej pożądane. W utworze skierowanym do Kazimierza Sapiehy poeta mówi o „przezacnych książętach” rodu, bez wskazania konkretnej postaci. Gdybyśmy zastosowali analogię do utworu poświęconego Małachowskiemu, to wśród najbliższych osób Kazimierza Nestora widzimy jego matkę, Elżbietę Sapieżynę, i wuja Franciszka Ksawerego Branickiego, którzy zwykle budzili emocje negatywne, a w czasie Sejmu Wielkiego wręcz złowrogie, co może tłumaczyć ich nieobecność w omawianym panegiryku. Dla Srzednickiego najważniejszy był adresat wiersza.

Niewątpliwego prestiżu Kazimierzowi Nestorowi Sapieże dodaje herb rodowy Lis, do którego znajdujemy w wierszu nawiązanie w postaci życzenia, aby pieczę nad generałem Sapiehą sprawowała strzała znajdująca się na tarczy herbowej rodu. Poeta wychwycił jeden, ale jakże znaczący element znajdujący się na herbie - strzałę, z którą wiąże się legenda. Poetycki opis herbu Sapiehów (z uwzględnieniem podania związanego ze strzałą) przedstawił Wacław Potocki:

Zwierz, rynsztunek i rzeka, Lis, krzyż, strzała Mzura -

Trzy rzeczy, które różni od siebie natura

Na jednym widząc herbie. Każdy tak tłumaczy,

${ }^{6}$ T. Zielińska, Poczet polskich rodów arystokratycznych, Wydawnictwa Szkolne i Pedagogiczne, Warszawa 1997, s. 390. 
Że rzeka miejsce onej okazyjej znaczy;

Kędy stawia Polakom nieprzyjaciel pole,

Lisa tam zażyć trzeba, gdzie kto Lwem nie zdole.

Tu jeden stary żołnierz do rady wezwany,

Postrzegłszy, że bez sztuki nie będzie wygranéj,

Z częścią wybranych ludzi - uszedłszy noc całą -

Wziął cel pogaństwu oraz wypuszczoną strzałą,

Do której zapalone przywiązuje knoty,

Pokaże czas królowi Marsowej roboty.

Takiem kształtem Ziemowit nieprzyjaciół gromi,

A temu, kiedy bijąc, dwa miecze przyłomi,

Dwa krzyże ich do strzały albo dwa ułomki

Wiecznem przyda na późne klejnotem potomki.

Stąd herb nazwany Lisem, który w hełmie stoi,

Przestrzegając, że rozum należy do zbroi;

Stąd wielkie familije rozumem i bronią

Widzimy tak pod Orłem, jako pod Pogonią?

Przywołując strzałę z herbu Lis, Srzednicki zdawał się przypomnieć dzielnego i dobrze służącego Kazimierzowi I Odnowicielowi rycerza z rodu Lisów, który dzięki wystrzelonej w niebo strzale wezwał posiłki i zyskał sławę w walce zwycięskiej z Jadźwingami. Taki antenat Sapiehów mógł być prawdziwą wizytówką patriotyzmu obecnego marszałka sejmowego. Byłoby to istotne w kontekście ówczesnych powiązań jego najbliższej rodziny z potemkinowską partią, jak i powszechnej nieufności do nadanego młodemu (bez zasług w wojskowości) Sapieże stopnia generała, zwłaszcza że współcześni obserwatorzy nie wykazywali zrozumienia dla takiego wywyższenia wchodzącego w życie dorosłe księcia. I chociaż w wierszu Srzednickiego nie ma mowy o zasługach adresata na polu walki, to autor dostrzegł w nim ducha bojowego (nazwał go „dzielnym”), dla którego tarczę obronną miały stanowić moździerz, armata i strzała herbowa. W swym panegiryzmie poeta szedł jeszcze dalej. Jego zdaniem „,buńczuch i buława” to za mało dla Sapiehy, a zatem używanie buńczuka oznaczającego władzę wojskową i piastowanie buławy nie wystarczają do tego, by w pełni do zasług uhonorować marszałka Sejmu Wielkiego.

Za najważniejszy atut Kazimierza Sapiehy poeta uznał jego dar wymowy, z którego słynął. Rzeczywiście talentu oratorskiego nie sposób odmówić Sapie-

${ }^{7}$ W. Potocki, Poczet herbów szlachty Korony Polskiej i Wielkiego Księstwa Litewskiego, gniazdo i perspektywa staroświeckiej cnoty płodnej matki, wszystkich świętych i świeckich ozdób przez [...], Wydawca Mikołaj Aleksander Schedel, Kraków 1696, s. 104-106. Zob. J. A. Gorczyn, Klejnoty abo herby państwa i rycerstwa, powiatów i miast głównych Korony Polskiej i Wielkiego Księstwa Litewskiego według obiecadła pamięci łacniejszej położone, Kraków 1630, s. 64. 
że. Krasomówstwo przyniosło mu miano „polskiego Cicerona” ${ }^{8} \mathrm{i}$ „polskiego Foksa". Srzednicki zestawił jego oratorstwo z „miodem płynącą Bernarda wymową" (w. 13). Efektowna stylistycznie metafora odnosząca się do „miodem płynącej wymowy" znana już była literaturze, chociaż nie należała do powszechnych. Kryli się pod nią najlepsi oratorzy. W Iliadzie przyznano ją Nestorowi: „Z ust jego słodsze płyną wyrazy od miodu"10. Obecna też była w poezji oświeceniowej. Adam Naruszewicz, poeta lubujący się w tworzeniu wyrażeń złożonych, pisał o „miodopłynnych słowach"11 Stanisława Augusta. Jeśli weźmiemy pod uwagę wysoką ocenę oratorstwa Sapiehy, nawet ponad wymowę króla, jak ocenił Schulz, to użytą przez Srzednickiego przenośnię należy uznać za uzasadnioną ${ }^{12}$, tyle tylko, że w odniesieniu do wymowy Sapiehy oprócz tego autora na taką metaforę nie zdobył się żaden inny poeta. Wskazując na analogię między sztuką oratorską marszałka Sejmu Wielkiego a darem wymowy kaznodziei Bernarda z Clairvaux, zwanego „doktorem miodopłynnym” (doctor mellifluus), poeta eksponował niedościgniony dar krasomówczy adresata, dając temu wyraz już w mottcie do utworu: Aurum et gemmae Sapientia est Labiis tuis. Piękna mowa Sapiehy płynie z ust złotem i klejnotami szlacheckimi. Motta tego nie udało się zlokalizować; najprawdopodobniej zostało skomponowane przez Srzednickiego dla potrzeb interesującego nas wiersza. Na przywołanie postaci św. Bernarda mógł wpłynąć fakt szerzenia kultu tego świętego, do czego w głównej mierze przyczynili się cystersi. W Polsce między innymi w malarstwie ściennym i ołtarzowym oraz w rzeźbie ukazywano jego wizerunki. W kontekście czasu powstania utworu (1790) znaczące wydaje się przeniesienie w tym samym roku relikwii św. Bernarda z Clairvaux do pobliskiego Ville-sous-la-Ferte ${ }^{13}$. Nie możemy też wykluczyć inspiracji płynących z literatury, chociażby ze strony Dantego, który wprowadził postać św. Bernarda do Bo-

${ }^{8}$ F. Schulz, Podróże Inflantczyka z Rygi do Warszawy i po Polsce w latach 1791-1793, w: Polska stanisławowska w oczach cudzoziemców, oprac. i wstępem poprzedził W. Zawadzki, t. 2, Państwowy Instytut Wydawniczy, Warszawa 1963, s. 615, Biblioteka pamiętników polskich i obcych.

9 J.E. Biester, Kilka listów o Polsce pisanych latem 1791 roku, w: Polska stanisławowska w oczach cudzoziemców..., t. 2, s. 215.

${ }^{10}$ Homer, Dzieła, t. 1: Iliada, przekł. F. K. Dmochowskiego, Druk. Księży Pijarów, Warszawa 1804 (Pieśń 1, w. 252).

${ }^{11}$ A. S. Naruszewicz, Wiersz radosny, czyli dytyramb z okazji zupetnego ozdrowienia Jego Królewskiej Mości, w: tegoż, Poezje zebrane, t. 1, wyd. B. Wolska, Instytut Badań Literackich PAN Wydawnictwo - Akademia Humanistyczna, Warszawa 2005, s. 115-123, Biblioteka Pisarzy Polskiego Oświecenia, t. 4: „Już jako pierwiej wesoły i zdrowy / miodopłynnymi wita wszystkich słowy" (w. 31-32).

${ }^{12}$ F. Schulz, dz. cyt., s. 615: „Książę Kazimierz Sapieha [...] mówił z większą łatwością niż król, ale także urywanym sposobem, z tymi samymi poruszeniami rąk...”.

${ }^{13}$ Informacje na temat Bernarda z Clairvaux za: Encyklopedia katolicka, t. 2, pod red. F. Gryglewicza, R. Łukaszyka, Z. Sułowskiego, Towarzystwo Naukowe Katolickiego Uniwersytetu Lubelskiego Jana Pawła II, Lublin 1976, s. 302-307, hasło: Bernard z Clairvaux (poszczególne fragmenty hasła oprac. przez wielu autorów). 
skiej komedii, aczkolwiek w dziele włoskiego poety św. Bernardowi wyznaczono inną rolę (- znawcy tajemnic nieba). Można przyjąć, że Srzednicki połączył ze sobą dwie sprawy: wybitne oratorstwo świętego i jego mir w społeczeństwie. Co prawda był to autorytet teologa średniowiecznego, ale w celu wywyższenia adresata utworu można było odwołać się nawet do świętego.

By ze zdolności oratorskich Sapiehy uczynić główny atut i cnotę, autor sięgnął po metaforykę z języka jubilerskiego, zestawiając słowa płynące z ust mówcy z nieskazitelnym diamentem. Słowa marszałka sejmowego warte są oszlifowanego diamentu, są brylantowe; inaczej ujmując: to słowa mistrzowskie. Ale „słowom wartym brylantowania" możemy nadać też inną konotację - odnieść je do doskonałych merytorycznie wystąpień Sapiehy w izbie sejmowej. Stawiając pytanie retoryczne - „Któryż jubiler będzie doskonały”, by stworzyć nieskazitelny diament? - poeta podnosił cenę tych słów. Swemu przeświadczeniu o randze wypowiedzi marszałka sejmowego nadał walor nieomylności, co znalazło potwierdzenie w powszechnej, jednoznacznej na ten temat opinii mieszkańców Korony Polskiej i Wielkiego Księstwa Litewskiego („W Koronie, w Litwie takie wszystkich zdania”, w. 6). W ten sposób autor stał się wyrazicielem poglądu zbiorowości, całej ojczyzny. Powszechność głoszonego poglądu poświadcza nadanie znaczenia semantycznego zaimkowi osobowemu liczby mnogiej „nam” (,świeć... nam do końca"). Wypowiedź autora rozwija się między adresatem wiersza a poetą i zbiorowością, czego świadectwem są zmieniające się formy gramatyczne.

Oprócz metaforycznego ujęcia oratorstwa Sapiehy w wierszu spotykamy metafory służące wyeksponowaniu wyjątkowych zasług adresata. Wśród nich ważną rolę wyznaczono hiperboli. Mądrość księcia jest niedościgniona w całym świecie, a co najwyżej można z trudem się do niej zbliżyć („ledwie jej świat ściga”); ogrom spływającego na niego splendoru oddaje wielkość całego gwiazdozbioru na niebie (,ile gwiazd ślicznych i na niebie słońca”), a ilość kwiatów w lecie (,ile niezwiędłych kwiatów lato wiąże”) posłużyła poecie do wyrażenia życzenia długich lat życia adresata. Duża hojność poety ujawniła się w zakresie stosowania epitetów. Książę Sapieha jest „prawdziwym Polakiem”, mądrym, dzielnym, najłaskawszym, szlachetnym człowiekiem (ma „wspaniałą duszę”). Są też epitety odnoszące się do pojęć abstrakcyjnych („dobro publiczne”, „wielka chwała”) i do właściwości przedmiotów, takie jak „niezwiędłe kwiaty”, „gwiazdy śliczne”, „wyryty marmur” czy „herbowna strzała”. Sformułowania personifikujące typu „świat ścigający mądrość” księcia, „ojczyzna zasługi wymierzająca”, „moździerz z armatą śmierć odgania" wpływają na obraz poetycki wiersza.

Chociaż nie jest to utwór bardzo wysokiego lotu, to jego autor wykazał się niezłą umiejętnością wierszowania. Stworzył regularny jedenastozgłoskowiec ze średniówką po piątej sylabie o rymach parzystych dokładnych.

A jakie zdanie na temat swego rymowania miał sam Ignacy Srzednicki? Uznał się za poetę przeciętnego, ,ani najlepszego, ani pośledniego”. I chociaż nie było to miejsce 
na warszawskim Parnasie, to miał nadzieję, że jego wiersz trafi do lektury. Jakby spodziewając się reakcji ze strony czytających, wychodził naprzeciwko ocenom i w przypadku braku akceptacji prosił o dokonanie korekty (,Zdaniem swym popraw, dość będzie honoru"). Taką deklaracją nie zaniedbał toposu skromności.

Okolicznościowy wiersz poświęcony Sapieże, chociaż nie został określony mianem ody, to stanowi realizację założeń tego gatunku literackiego. Wypowiedź poety skierowana została do adresata godnego pochwały wynikającej z pełnionej funkcji marszałka Sejmu Wielkiego, a użyte w wierszu metafory, apostrofy czy wręcz aklamacje nadały mu uroczysty charakter, zapewniając zarazem sugestywność oddziaływania na odbiorców.

\section{Aneks}

Jaśnie Oświeconemu Księciu Jmci Saphyi, generałowi szefowi artyl[erii] W[ielkiego] Ks[ięstwa] Lit[ewskiego], marszałkowi Skonf[ederowanych] Stanów Najjaś[niejszej] Rze[czy]p[ospo]1[i]tej Polskiej z Wielkiego Księstwa Litewskiego.

Wielkiemu niespracowanemu dzielnej duszy mężowi wieśniak spod cienia wiejskiego stanu na wielki i wysoki świat przybywszy dzieło swoje partykularne w ręce Pańskie ofiaruję

Aurum et gemmae Sapientia est Labiis tuis

Ledwie ojczyzna tak mądrego miała

Księcia Saphija, szefa - generała,

Książę! Twa mądrość, ledwie jej świat ściga,

Dobro publiczne dla ojczyzny dźwiga.

Wybór słów Twoich wart brylantowania -

W Koronie, w Litwie takie wszystkich zdania.

Któryż jubiler będzie doskonały?

W potomne wieki warteś wielkiej chwały!

Przezacnych książąt dzielny jedynaku,

Wierze, wolności, prawdziwy Polaku;

Wspaniała dusza Księcia Kazimierza -

Niech mu ojczyzna zasługi wymierza!

Miodem płynąca Bernarda wymowa,

W wielkim szacunku wszystkie Twoje słowa;

Mało dla Ciebie bończuch i buława,

Wyryty marmur: z wieku na wiek - sława!

Żyj z wieku na wiek, najłaskawszy Książę,

Ile niezwiędłych lato kwiatów wiąże.

Cała-ć ojczyzna te chęci nakłania, 
Moździerz z armatą niech śmierć precz odgania!

Herbowna w sukurs niechaj spieszy strzała,

Broni swojego szefa - generała.

Świeć swą splędecą, Książę, nam do końca,

Ile gwiazd ślicznych i na niebie słońca.

\section{Addytament}

Ganić, poprawić lub odpisać ile

Bez braku wzajem chwalić będę style.

Ludzkie roboty z wątłej ich natury

Jedni pochwalą, drudzy - do cenzury.

Nie można zgadnąć ludzkiego humoru,

Zdaniem swym popraw, dość będzie honoru.

Imię Ignacy na Srzednicy Srzedni

Ani najlepszy, ani też pośledni.

Obywatel W[ojewó]dztwa Podlaskiego Ziemi Bielsk[iej],

najlichszy sługa Pański

Srzednicki

Zasady transkypcji utworu według wzoru w: Wiersze polityczne Sejmu Czteroletniego, czéść pierwsza 1788-1789. Z papierów E. Rabowicza oprac. K. Maksimowicz, Warszawa 1998, s. 24-25, Poezja Polityczna Sejmów Doby Oświecenia.

\section{Bibliografia}

\section{Podmiotowa}

Biester Johann Erich, Kilka listów o Polsce pisanych latem 1791 roku, w: Polska stanistawowska w oczach cudzoziemców, oprac. i wstępem poprzedził W. Zawadzki, t. 2, Państwowe Wydawnictwo Naukowe, Warszawa 1963, s. 185-242.

Estreicher Karol, Bibliografia polska, cz. 3, t. 29 (40), wyd. S. Estreicher, nakł. Polskiej Akademii Umiejętności, Kraków 1933.

Gorczyn Jan Aleksander, Klejnoty abo herby państwa i rycerstwa, powiatów i miast głównych Korony Polskiej i Wielkiego Księstwa Litewskiego według obiecadła pamięci łacniejszej potożone, Kraków 1630.

Homer, Dzieła, t. 1: Iliada, przekł. Franciszka Ksawerego Dmochowskiego, Druk. Księży Pijarów, Warszawa 1804.

Naruszewicz Adam Stanisław, Wiersz radosny, czyli dytyramb z okazji zupetnego ozdrowienia Jego Królewskiej Mości, w: tegoż, Poezje zebrane, t. 1, wyd. B. Wolska, Instytut Badań Literackich PAN Wydawnictwo - Akademia Humanistyczna, Warszawa 2005, s. 115-123, Biblioteka Pisarzy Polskiego Oświecenia, t. 4.

Potocki Wacław, Poczet herbów szlachty Korony Polskiej i Wielkiego Księstwa Litewskiego, gniazdo i perspektywa staroświeckiej cnoty płodnej matki, wszystkich świętych i świeckich ozdób przez [...], Wydawca Mikołaj Aleksander Schedel, Kraków 1696. 
Schulz Friedrich, Podróże Inflantczyka z Rygi do Warszawy i po Polsce w latach 1791-1793, w: Polska stanisławowska w oczach cudzoziemców, oprac. i wstępem poprzedził W. Zawadzki, t. 2, Państwowy Instytut Wydawniczy, Warszawa 1963, s. 281-673, Biblioteka pamiętników polskich i obcych.

Śrzednicki Ignacy, Jaśnie Oświeconemu Księciu Jmci Saphyi, generałowi szefowi artyl[erii] W[ielkiego] Ks[ięstwa] Lit[ewskiego], marszałkowi Skonf[ederowanych] Stanów Najjaś[niejszej] Rze[czy]p[ospo]l[i]tej Polskiej z Wielkiego Księstwa Litewskiego. Wielkiemu niespracowaneтu dzielnej duszy mężowi wieśniak spod cienia wiejskiego stanu na wielki $i$ wysoki świat przybywszy dzieło moje partykularne w ręce Pańskie ofiaruję, b.m.r., k. nlb. 2: Biblioteka Instytutu Badań Literackich w Warszawie, sygn. XVIII 2.193; Biblioteka Wojewódzka w Kielcach, sygn. Qu 895 adl.; Biblioteka im. Ossolińskich we Wrocławiu, sygn. XVIII 8575. Wyd. cyfrowe $\mathrm{z}$ egz. w IBL.

Śrzednicki Ignacy: Jaśnie Wiel[możnemu] na Małachowicach Nałęcz Małachowskiemu, referend[arzowi] koron[nemu], marszałkowi Najjaś[niejszej] Rze[czy]p[ospo]l[i]tej Polskiej Skonf[ederowanych] Stanów Koronnych, Kawalerowi Orderów Orła Białego i Św. Stanisława. Sandeckiemu, Knyszyńskiemu etc. Staroście. Wielkiemu niespracowanemu dzielnej duszy mężowi wieśniak spod cienia wiejskiego stanu na wielki $i$ wysoki świat przybywszy dzieło swoje partykularne w ręce Pańskie ofiaruję, b.m.r., k. nlb. 2: Biblioteka Instytutu Badań Literackich w Warszawie, sygn. XVIII 2.192. Wyd. cyfrowe z tego egz.

\section{Przedmiotowa}

Encyklopedia katolicka, t. 2, pod red. F. Gryglewicza, R. Łukaszyka, Z. Sułowskiego, Towarzystwo Naukowe Katolickiego Uniwersytetu Lubelskiego Jana Pawła II, Lublin 1976, s. 302-307, hasło: Bernard z Clairvaux.

Słownik geograficzny Królestwa Polskiego i innych krajów słowiańskich, nakł. F. Sulimierskiego i W. Walewskiego, t. 4, Warszawa 1883.

Szczepaniec Józef, Drukarnia Wolna Jana Potockiego w Warszawie 1788-1792, Wydawnictwo Uniwersytetu Wrocławskiego, Wrocław 1998.

Wiersze polityczne Sejmu Czteroletniego, część pierwsza 1788-1789. Z papierów E. Rabowicza oprac. K. Maksimowicz, Warszawa 1998 (w serii: Poezja Polityczna Sejmów Doby Oświecenia).

www.katalogszlachty.com; dostęp: 10.02.2016 r.

Zielińska Teresa, Poczet polskich rodów arystokratycznych, Wydawnictwa Szkolne i Pedagogiczne, Warszawa 1997.

Krystyna Maksimowicz

\section{Forgotten panegyric of Ignacy Srzednicki in honour of Kazimierz Nestor Sapieha}

(Summary)

The poem of Ignacy Srzednicki addressed to Kazimierz Nestor Sapieha was created during the Great Sejm, when the addressee served as the Speaker of the Seimas and the General Confederation of the Polish-Lithuanian Commonwealth. The author reconstructs the biography of the creator of the poem, explores the relationship between Srzednicki and Sapieha, as well as analyses and interprets the poem included in the appendix.

Keywords: Ignacy Srzednicki; Kazimierz Nestor Sapieha; panegyric; the Great Sejm

Słowa kluczowe: Ignacy Srzednicki; Kazimierz Nestor Sapieha; panegiryk; Sejm Wielki 